\title{
16. CHEMISTRY, CARBON AND OXYGEN ISOTOPE RATIOS, AND ORIGIN OF DEEP-SEA CARBONATES AT SITES 438, 439, AND 584: INNER SLOPE OF THE JAPAN TRENCH ${ }^{1}$
}

\author{
Ryo Matsumoto, Geological Institute, University of Tokyo \\ and \\ Yukihiro Matsuhisa, Mineral Deposits Department, Geological Survey of Japan²
}

\begin{abstract}
Carbonate concretions in Pliocene to Miocene diatomaceous sediments at Sites 438, 439, and 584 on the deep-sea terrace near the Japan Trench are composed of calcite, dolomite, and siderite with varying degrees of chemical substitution. $\delta^{18} \mathrm{O}$ ranges from -0.81 to $+5.15 \%$ for calcite and +2.00 to $+7.29 \%$ for dolomite. $\delta^{13} \mathrm{C}$ values vary widely between -36.96 and $+11.45 \%$ for calcite and between -20.99 and $+4.75 \%$ for dolomite. Siderite has $-1.90 \% 0 \delta^{18} \mathrm{O}$ and $+0.03 \%_{0} \delta^{13} \mathrm{C}$. The depth of burial at which these carbonates precipitated is estimated using the "oxygen isotope thermometer" on the basis of $\delta^{18} \mathrm{O}$ values of carbonates and the interstitial water, and the geothermal gradients measured at present. Based on the estimated depth of formation of carbonates, four stages of carbonate authigenesis are defined, Stage I (0-20 m sub-bottom depth, calcian dolomite), Stage IIa (20-250 m sub-bottom depth, magnesian calcite), Stage IIb (250-530 m sub-bottom depth, ferroan calcite), Stage III (530-590 m sub-bottom depth, ferroan dolomite), and Stage IV (590 m to total depth, siderite). The progressive changes in mineralogy and chemistry of authigenic carbonates are well matched with the variation of the chemical composition of the interstitial water with increasing depth. The fluctuation of $\delta^{13} \mathrm{C}$ of carbonates reflects the changing origin of $\mathrm{CO}_{2}$; oxidation and sulfate reduction at Stages I and IIa; and methane fermentation at Stages IIb, III, and IV.
\end{abstract}

\section{INTRODUCTION}

Sediment samples recovered by the Glomar Challenger show progressive diagenetic changes in mineralogy, chemistry, and textures with increasing depth of burial. These changes can be explained as the result of (1) diagenetic modification of the primary sediment, and (2) differences in sediment lithology throughout time. Although the vertical distribution of authigenic minerals is frequently used as an indicator of diagenesis, the subbottom depth at which the authigenic minerals occur does not always coincide with the depth at which they precipitated; authigenic minerals may have formed at shallower depths and then may have been buried in their present positions, or they may have formed at deeper levels but were "elevated" later by subaqueous erosion. Thus, determination of the depth of burial at which authigenic minerals precipitated is not always straightforward.

We studied carbonate concretions recovered from the Pliocene to Miocene diatomaceous mudstone at Site 584 (Leg 87) in the Japan Trench region. Carbonate concretions have also been reported from Sites 438 and 439 of Leg 57, located about $60 \mathrm{~km}$ northwest of Site 584 (Matsumoto and Iijima, 1980). Carbonate concretions are perhaps the most typical and attractive products of diagenesis; there can be no doubt that they form in the sediments during diagenesis. Their mineralogy and chemistry and their textural relations with the enclosing sediments record the physicochemical conditions of the

\footnotetext{
${ }^{1}$ Kagami, H., Karig, D. E., Coulbourn, W. T., et al., Init. Repts. DSDP, 87: Washington (U.S. Govt. Printing Office),

2 Addresses: (Matsumoto) Geological Institute, Faculty of Science, University of Tokyo, Hongo, Bunkyo-ku, Tokyo 113, Japan; (Matsuhisa) Mineral Deposits Department, Geological Survey of Japan, 1-1-3 Yatabe-Higashi, Ibaraki 305, Japan.
}

sediments at a certain diagenetic stage. In other words, carbonate concretions are considered as "fossils" of diagenetic environments. Therefore, it is very important to estimate the depth of formation of the concretion as accurately as possible.

Using the oxygen isotope ratio, Hein and others (1979) estimated the depth of formation of calcite and dolomite in deep-sea sediments. Their calculations were based on the assumption that $\delta^{18} \mathrm{O}$ of the interstitial water was $0 \%$ (present seawater value) throughout the cores regardless of burial depth; $\delta^{18} \mathrm{O}$ values of the interstitial water may change significantly with depth, especially if much altered volcanic debris occurs within the sediments (Lawrence et al., 1975). In this paper, we will analyze the chemical composition and carbon and oxygen isotopic composition of selected authigenic carbonates, and we will apply the "oxygen isotope thermometer" to estimate the depth of precipitation of authigenic carbonates; we fortunately have both $\delta^{18} \mathrm{O}$ data for interstitial water and geothermal gradients at the studied sites. Lastly, we will discuss carbonate authigenesis in the context of the evolution of interstitial water chemistry.

\section{PLIOCENE TO MIOCENE SEDIMENTS AT SITES 438, 439, AND 584}

The sediment samples studied for this report were taken from Sites 438 and 439 of Leg 57 and Site 584 of Leg 87 in the Japan Trench region off northeastern Honshu, Japan. Sites 438 and 439 are located on a deep-sea terrace about $150 \mathrm{~km}$ east of Hachinohe at a water depth of $1600 \mathrm{~m}$. Site 584 is located on a midslope terrace, about $60 \mathrm{~km}$ southeast of Sites 438 and 439; the water depth is $4094 \mathrm{~m}$ (Fig. 1). Sediments from Sites 438 and 439 range in age from Pleistocene to Cretaceous(?), and 


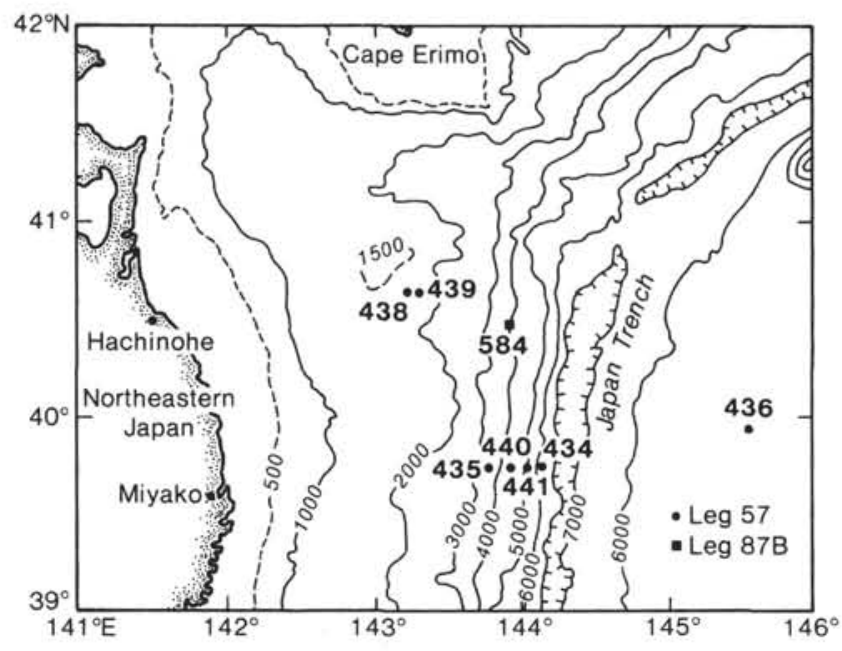

Figure 1. Bathymetry and locations of DSDP sites near the Japan Trench. Carbonate samples were taken from Sites 438, 439, and 584. Geothermal gradients have been given for Sites 438, 439, and 440.

Site 584 sediments are Pleistocene, Pliocene, and Miocene (Fig. 2).

Pliocene to Miocene sediments from these sites are mainly diatomaceous siliceous mud and mudstone with sporadic muddy turbidites in the middle Miocene section and thin ash layers at the top and lower horizons. Siliceous skeletons such as diatom frustules, sponge spicules, and radiolarian tests commonly make up 50 to 70 vol. \% of the sediment (according to smear-slide observations); the silica content measured by $\mathrm{X}$-ray fluorescence (XRF) analysis is 70 to $80 \mathrm{wt} . \%$ on a water-free basis. Calcareous fossils, such as nannoplankton and foraminifers, are scarce throughout the Pliocene to Miocene sediments, except for a thin biogenic calcareous bed at about $270 \mathrm{~m}$ sub-bottom.

As determined by the diatom biostratigraphy (Akiba, this volume) and paleomagnetic data (Niitsuma, this volume), the sediment accumulation rate at Site 584 is very high $(\sim 160 \mathrm{~m} / \mathrm{Ma})$ for the upper horizon between 50 and $580 \mathrm{~m}$ sub-bottom and the lower horizon below 650 $\mathrm{m}$, whereas it is very low (less than $20 \mathrm{~m} / \mathrm{Ma}$ ) for the top horizon and the middle horizon between 580 and $650 \mathrm{~m}$. The fluctuation of the sediment accumulation rates at Sites 438 and 439 is similar to that at Site 584 (Scientific Party, 1980).

\section{AUTHIGENIC CARBONATES}

\section{Occurrence of Authigenic Carbonates}

Light-colored, hard, dense carbonate concretions, usually a few $\mathrm{cm}$ to $20 \mathrm{~cm}$ in thickness, occur in the diatomaceous sediment. They seem to congregate at several specific horizons, especially above $100 \mathrm{~m}$ sub-bottom depth, at $\sim 600 \mathrm{~m}$ and below $850 \mathrm{~m}$ sub-bottom (Fig. 2). Upper Miocene to Pliocene sediments between 100 and $600 \mathrm{~m}$ sub-bottom lack carbonate concretions. This "nonconcretionary zone" coincides with rapidly deposited sediments. Conversely, a "concretionary zone" appears to occur in slowly deposited sediments. The carbonate

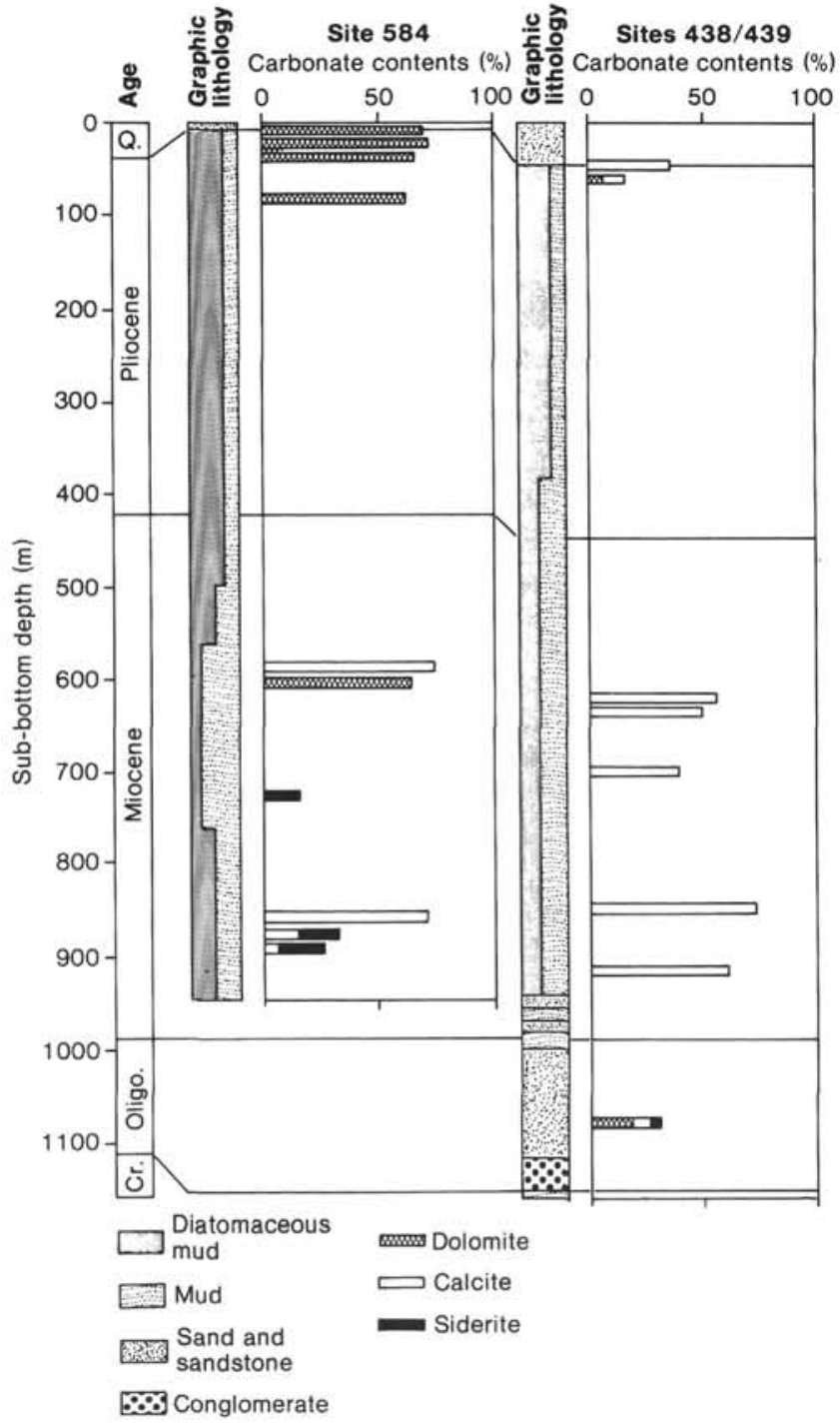

Figure 2. Sediment lithology and horizons, and carbonate contents of carbonate concretions at Sites $438 / 439$ and 584 .

content of these concretions ranges widely from 15 to 73 wt. \% (Fig. 2).

The carbonate minerals making up these concretions are calcite, dolomite, and siderite with variable chemical composition. At Sites 438 and 439 , calcite is dominant and dolomite and siderite are rare, whereas at Site 584, calcite and siderite are less common and dolomite is common. Most concretions contain only one carbonate mineral but some consist of two or even three carbonate minerals, such as the calcite-siderite concretion (58492-1, 31-32 cm) or the calcite-siderite-dolomite concretion (438A-5-4, 106-108 cm). Dolomite tends to occur both at shallow stratigraphic levels above $100 \mathrm{~m}$ subbottom and at deeper levels ( $\sim 600 \mathrm{~m}$ sub-bottom). Siderite occurs at deeper levels below $700 \mathrm{~m}$ sub-bottom, whereas calcite occurs throughout the Miocene to Pliocene sediments. Thus, it is difficult to distinguish specific carbonate mineral zones in these sediments.

Scanning electron micrographs of carbonate concretions show euhedral crystals and microaggregates filling 
interstices of siliceous skeletons and terrigenous detrital grains (Fig. 3A-B). Dolomite concretions from shallow cores (584-2,CC; 584-9-1, 4-6 cm) are composed of subhedral dolomite grains growing on and within diatom frustules and sponge spicules. Individual dolomite crystals exhibit sharp edges and smooth surfaces and are usually 3-5 $\mu \mathrm{m}$ in diameter. Siliceous skeletons in these dolomitic samples are not dissolved at all. A siderite concretions at approximately $720 \mathrm{~m}$ sub-bottom is characterized by microspherulitic aggregates (Fig. 3C). Microspherulites are about $1-2 \mu \mathrm{m}$ in diameter and are made up of minute rhombohedral grains of $0.1-0.3 \mu \mathrm{m}$. A siderite concretion from the deeper core at approximately $870 \mathrm{~m}$ sub-bottom contains larger rhombohedral siderite grains (Fig. 3D).

\section{Chemical Composition of Authigenic Carbonates}

Chemical compositions of authigenic carbonates were determined chiefly by an X-ray microanalyzer JXA-5. An EDX analyzer, Hitachi S-450 equipped with a Kevex 7000 analyzing system, was used for the minute aggregates and crystal grains less than $2 \mu \mathrm{m}$ across. No significant compositional differences exist between carbonates of Sites 438 and 439 and those of Site 584 (Fig. 4).
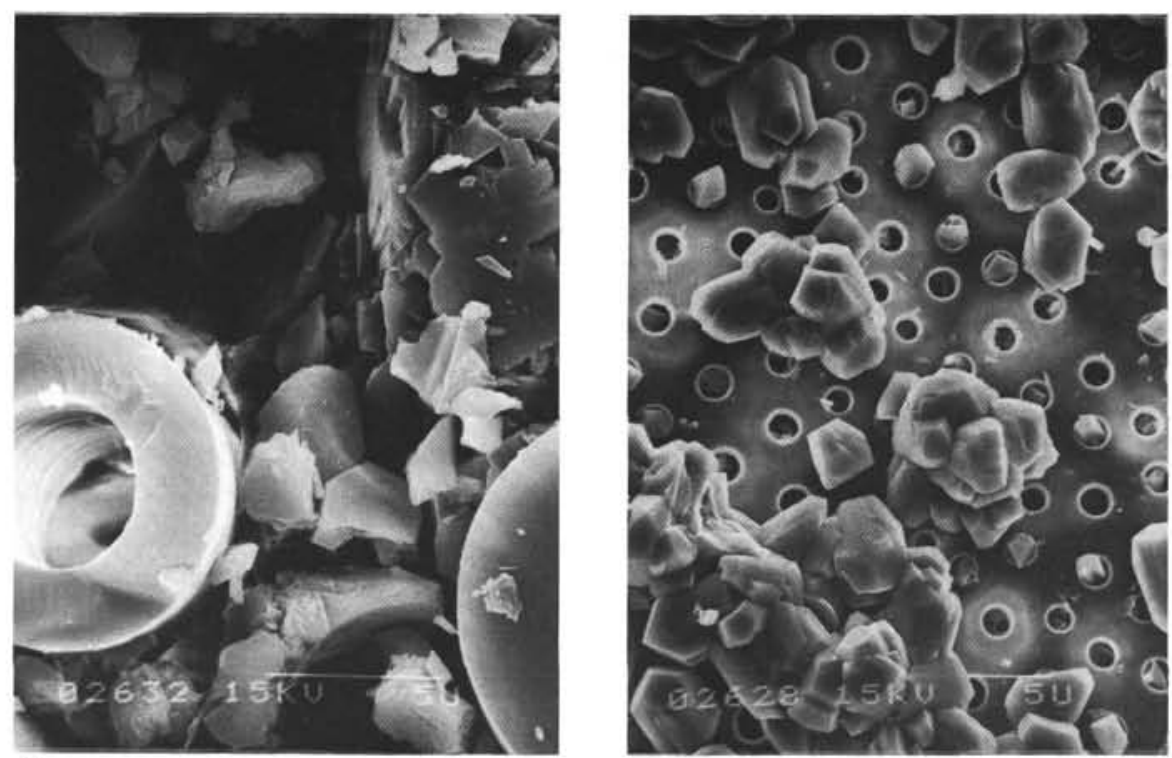

A

B
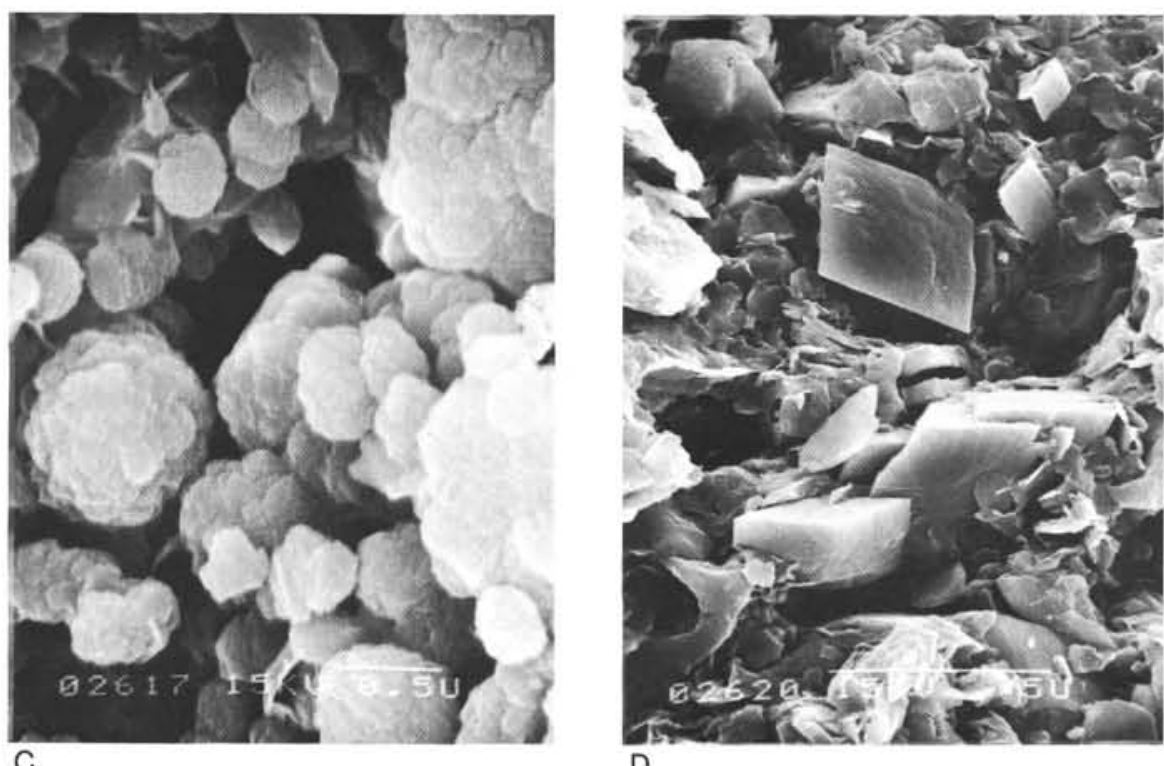

D

Figure 3. Scanning electron micrographs of carbonate concretions. A. Dolomite cement filling interstices of sponge spicules (large circles) $(584-2, \mathrm{CC})$. B. Polygonal dolomite grains growing on diatom frustule (584-9-1, 4-6 cm). Note that siliceous skeletons are not dissolved in these dolomite concretions (A and B). C. Microspherules of siderite in calcite-siderite concretion (584-76-1, 145-146 cm). D. Large rhombohedral siderite in siderite concretion (584-93-2, 85$86 \mathrm{~cm}$ ). Siliceous skeletons are partly dissolved in these deeper sample (C and D). 


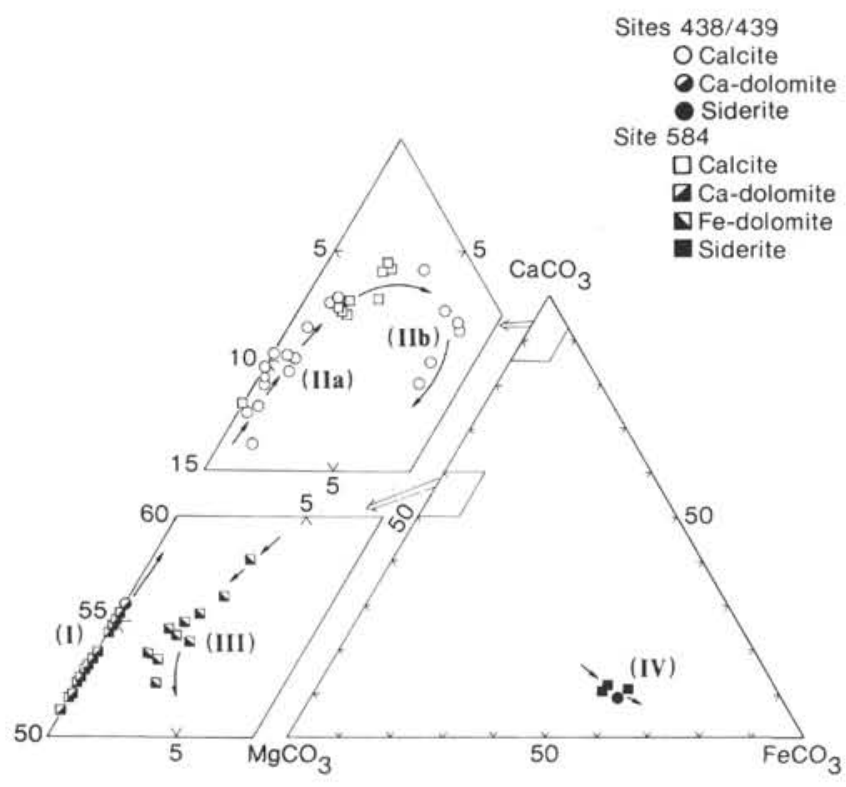

Figure 4. Chemical composition of authigenic carbonates represented in mole percent. Mn content is less than $0.5 \mathrm{~mol} . \%$ in all carbonates. Solid arrows show the sequence of formation of authigenic carbonates. Stages I, IIa, IIb, III, and IV indicate the stages of carbonate authigenesis (see text for explanation of stages).

Compositional zoning within a single grain of authigenic carbonate was not detected because of the small size, usually $\sim 2-5 \mu \mathrm{m}$ and sometimes less than $1 \mu \mathrm{m}$.

Calcite exhibits a wide range of composition from high-magnesian-low-iron calcite to low-magnesian-highiron calcite. The content of $\mathrm{Mg}$ ranges between 2.0 and $12.2 \mathrm{~mol} . \%$ and the $\mathrm{Fe}$ content ranges from 0 to 6.5 mol.\%. Calcite from shallowly buried sediments (438A$3-6,134-136 \mathrm{~cm})$ is the high-magnesian type, whereas calcite from more deeply buried sediments (below $\sim 600$ $\mathrm{m}$; see Fig. 2) is either high magnesian and/or ferroan. Dolomite is classified into two groups based on the iron content (Fig. 4). One is calcian dolomite with 1 to 6 mol. \% excess $\mathrm{Ca}$ and less than $0.1 \mathrm{~mol} . \% \mathrm{Fe}$, and the other is ferroan dolomite with 2 to $8 \mathrm{~mol} . \%$ excess $\mathrm{Ca}$ and 2.5 to 4 mol.\% Fe. Ferroan dolomite is contained exclusively in the dolomite concretion at $610 \mathrm{~m}$ sub-bottom, whereas calcian dolomite occurs at higher stratigraphic levels. Siderite is highly magnesian with 30 to 34 $\mathrm{mol} . \% \mathrm{Mg}$ and 10 to $13 \mathrm{~mol} . \% \mathrm{Ca}$.

\section{Carbon and Oxygen Isotope Ratio of Carbonates}

Carbon and oxygen isotope ratios were determined for concretions with only one carbonate mineral present; carbonate concretions that contained two or more carbonate minerals were excluded because it is generally difficult to measure the isotope ratio of the individual carbonate phases. Pulverized carbonate samples were dissolved in $100 \%$ phosphoric acid at $25^{\circ} \mathrm{C}$, and the resulting $\mathrm{CO}_{2}$ was purified. Acid treatment for calcite took 20 hr., whereas more than $72 \mathrm{hr}$. were needed for dolomite and siderite. ${ }^{44} \mathrm{CO}_{2},{ }^{45} \mathrm{CO}_{2}$, and ${ }^{46} \mathrm{CO}_{2}$ were analyzed by mass spectrometer (MAT 250) at the Geological Survey of Japan at Tsukuba. Standard deviation of analysis and reproducibility are 0.02 and $0.1 \%$ respectively.

Carbon isotope ratios exhibit a much greater variation than the oxygen isotope ratios (Table 1; Fig. 5). For calcite, $\delta^{13} \mathrm{C}$ ranges from -37.0 to $+11.5 \%$, whereas $\delta^{18} \mathrm{O}$ varies between -0.8 and $+5.1 \%$. Light carbon calcites (438A-3-6, 134-136 cm; 438A-68-2, 24-26 cm; $438 \mathrm{~A}-60-2,32-35 \mathrm{~cm} ; 584-63-1,73-75 \mathrm{~cm})$ are all of the

Table 1. Carbon and oxygen isotope ratios and depth of formation of authigenic carbonates.

\begin{tabular}{|c|c|c|c|c|c|c|c|}
\hline $\begin{array}{l}\text { Carbonate concretions } \\
\text { (Hole-Core-Section, } \\
\text { interval in } \mathrm{cm} \text { ) }\end{array}$ & $\begin{array}{l}\text { Authigenic } \\
\text { carbonates }\end{array}$ & $\begin{array}{c}\text { Depth of } \\
\text { occurrence }(m) \\
\left(d_{1}\right)\end{array}$ & ${ }_{\delta}^{13} \mathrm{C}$ & ${ }_{\delta^{18} \mathrm{O}}$ & $\begin{array}{c}\delta^{18} \mathrm{O} \\
\text { (corrected for } \\
\text { Mg-substitution) }\end{array}$ & $\begin{array}{c}\text { Depth of } \\
\text { formation }(m) \\
\left(d_{2}\right)\end{array}$ & $\begin{array}{c}\Delta d(m) \\
\left(d_{1}-d_{2}\right)\end{array}$ \\
\hline \multicolumn{8}{|l|}{ Leg 87, Site 584} \\
\hline $584 \mathrm{~A} \cdot \mathrm{H} 1-6,135-137$ & Ca-dolomite & 8.9 & -13.52 & +7.02 & & 8 & 1 \\
\hline $584 \mathrm{~A}-\mathrm{HI}-6,135-137$ & Ca-dolomite (vein) & (vein) & -20.63 & +7.29 & & & \\
\hline $584-2, \mathrm{CC} 10.2^{*}$ & Ca-dolomite & 16.3 & -20.99 & +6.97 & & 7 & 9 \\
\hline $584-2$, CC $10.0^{*}$ & Ca-dolomite & 16.3 & -20.93 & +6.66 & & 7 & 9 \\
\hline $584-2$, CC $8.0^{*}$ & Ca-dolomite & 16.3 & -18.24 & +6.90 & & 7 & 9 \\
\hline $584-2, \mathrm{CC} 6.0^{*}$ & Ca-dolomite & 16.3 & -19.06 & +6.31 & & 7 & 9 \\
\hline $584-2, \mathrm{CC} 3.0^{*}$ & Ca-dolomite & 16.4 & -21.30 & +6.68 & & 7 & 9 \\
\hline $584-2, \mathrm{CC} 0.5^{*}$ & Ca-dolomite & 16.4 & -21.38 & +6.74 & & 7 & 9 \\
\hline $584-3-1,0-3$ & Ca-dolomite & 20.1 & -18.91 & +7.21 & & 15 & 5 \\
\hline $584-9-1,4-6$ & Ca-dolomite & 77.1 & -18.35 & +7.21 & & 15 & 62 \\
\hline $584-63-1,73-75$ & Calcite & 594.3 & -33.41 & +4.43 & +3.71 & 60 & 534 \\
\hline $584 \mathrm{~A}-\mathrm{H} 1, \mathrm{CC}$ & Fe-dolomite & $610(?)$ & +4.75 & +2.00 & & 580 & 30 \\
\hline $584-76-1,145-146$ & Siderite & 720.1 & +0.03 & -1.90 & & 600 & 120 \\
\hline $584 \mathrm{~B}-\mathrm{H} 3, \mathrm{CC}$ & Calcite & $850(?)$ & -4.43 & +1.45 & +1.24 to +1.06 & 345 & 505 \\
\hline \multicolumn{8}{|l|}{ Leg 57 , Sites 438 and 439} \\
\hline $438 \mathrm{~A}-3-6,134-136$ & Calcite & 40.8 & -24.15 & +5.15 & +4.52 to +4.43 & $25(?)$ & 16 \\
\hline $438 \mathrm{~A}-60-1,94-96$ & Calcite & 622.5 & +11.45 & -0.81 & -1.05 to -1.11 & 480 & 143 \\
\hline $438 \mathrm{~A}-60-2,32-35$ & Calcite & 523.8 & -36.96 & +4.14 & +3.60 to +3.54 & 55 & 569 \\
\hline $438 \mathrm{~A}-68-2,24-26$ & Calcite & 699.2 & -27.19 & +3.34 & +2.92 & 120 & 579 \\
\hline $439-5-2,8-10$ & Calcite & 851.0 & -4.33 & +2.88 & +2.34 to +2.31 & 165 & 686 \\
\hline $439-11, \mathrm{CC}$ & Calcite & 911.7 & -2.24 & +0.33 & +0.24 to +0.21 & 350 & 562 \\
\hline
\end{tabular}

Note: $\delta^{13} \mathrm{C}$ and $\delta^{18} \mathrm{O}$ expressed in $\%_{0}$ versus PDB standard. $\delta^{18} \mathrm{O}$ values of dolomite are corrected by $-0.8 \%_{0}$ after Sharma and Clayton (1965). Marked interval (*) designates distance from the bottom of the concretion (in $\mathrm{cm}$ ) (see Fig. 6). 


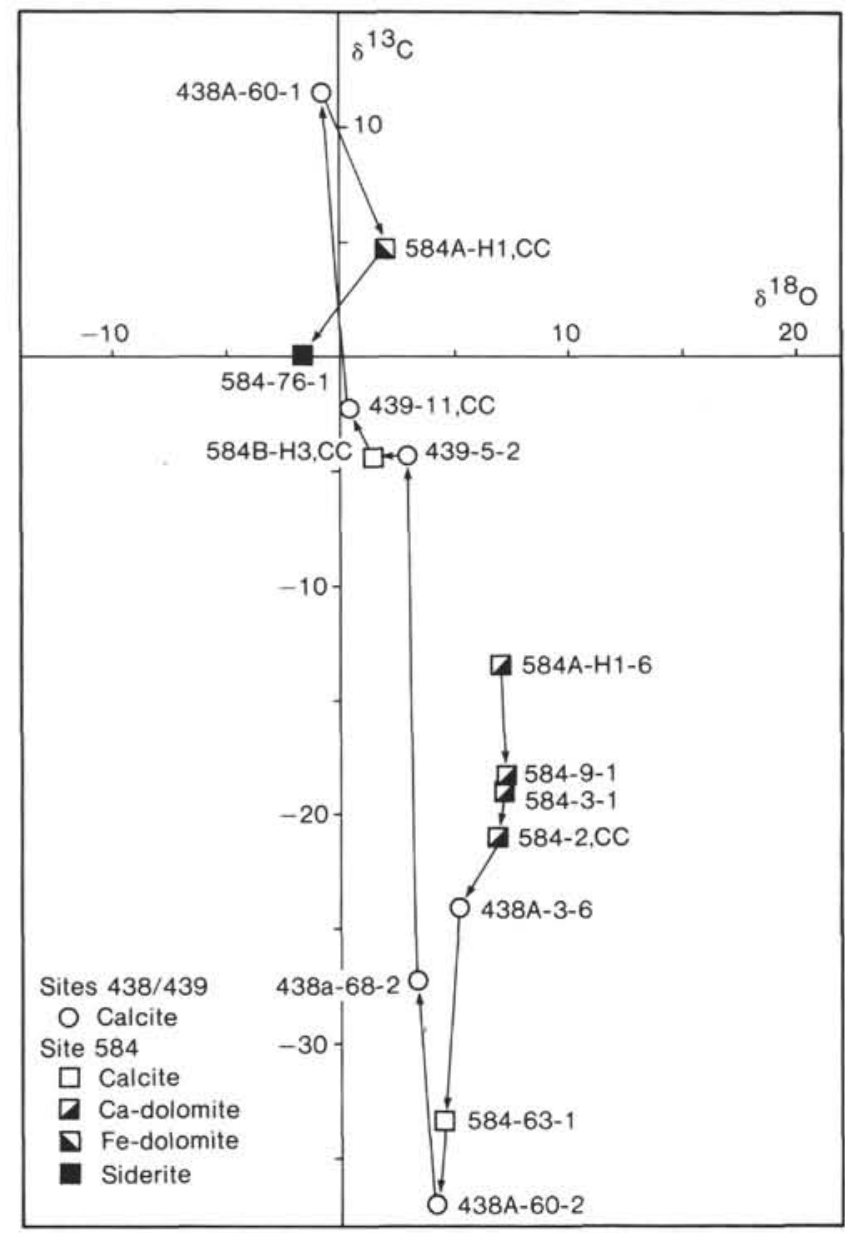

Figure 5. Carbon and oxygen isotope ratios of authigenic carbonates represented in $\%_{0}$ versus PDB standard. Arrows indicate the sequence of formation of authigenic carbonates. Location is expressed in hole-core-section.

high-magnesian type, with more than $8 \mathrm{~mol} \% \mathrm{Mg}$, whereas heavy carbon calcites (438A-60-1, 94-96 cm; 439-11,CC; 439-5-2, 8-10 cm; 584A-H3,CC) are either high-magnesian or ferroan type. Siderite has a $\delta^{13} \mathrm{C}$ of $+0.03 \%$ and a $\delta^{18} \mathrm{O}$ of $-1.9 \%$; the oxygen value of siderite is the lowest among all the carbonates analyzed here. Dolomite is separated into light and heavy carbon types; all the light carbon types are calcian dolomite found in shallow stratigraphic levels, whereas heavy carbon dolomite $(584 \mathrm{~A}-\mathrm{H} 1, \mathrm{CC})$ is ferroan. Dolomite tends to concentrate ${ }^{18} \mathrm{O}$ relative to calcite and siderite (Fig. 5).

Zonal distribution of $\delta^{13} \mathrm{C}$ and $\delta^{18} \mathrm{O}$ within a dolomite concretion $(584-2, \mathrm{CC})$ is shown in Figure $6 . \delta^{18} \mathrm{O}$ slightly increases from $+6.3 \%$ at the center to $+6.7 \%$ at the rim of the concretion, whereas $\delta^{13} \mathrm{C}$ decreases outwards from -18 to $-21 \%$. Based on this compositional zoning of $\delta^{13} \mathrm{O}$ and $\delta^{18} \mathrm{O}$ in a single dolomite concretion, the order of formation of calcian dolomite starting with the first formed is assumed to be from 584A-H1-6 $\left(-13.5 \%_{0} \delta^{13} \mathrm{C},+7.0 \%_{0} \delta^{18} \mathrm{O}\right)$ to $584-2, \mathrm{CC}(-21.0 \% 0$, $+7.0 \%$ ) through $584-9-1(-18.4 \% 0,+7.2 \% 0)$ and $584-$ 3-1 (-18.9\%o, +7.2\% ) (Fig. 5).

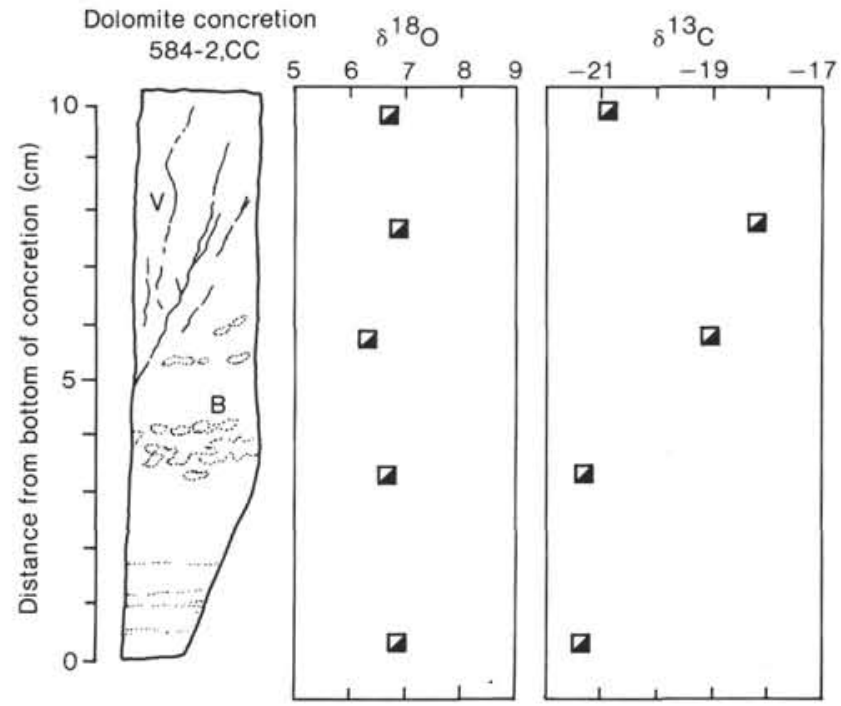

Figure 6. Compositional zoning within dolomite concretion. $\mathrm{V}=$ dewatering veins; $\mathrm{B}=$ burrows. $\delta^{18} \mathrm{O}$ and $\delta^{13} \mathrm{C}$ are expressed in $\%$ versus PDB standard.

\section{OXYGEN ISOTOPE RATIO OF THE INTERSTITIAL WATER}

At Site 584 interstitial water was squeezed from the sediment cores immediately after recovery by a "Manheim Squeezer" at intervals of 15 to $40 \mathrm{~cm}$ of selected cores between 5 and $600 \mathrm{~m}$ sub-bottom. $\delta^{18} \mathrm{O}$ of the interstitial water increases slightly to $+0.7 \%$ at very shallow levels above $24.5 \mathrm{~m}$, but below that depth it decreases gradually at an approximate rate of $-0.26 \%$ per $100 \mathrm{~m}$ to $-0.9 \%$ at $590.1 \mathrm{~m}$ sub-bottom (Fig. 7; Matsuhisa and Matsumoto, this volume).

$\delta^{18} \mathrm{O}$ of the interstitial water was not reported at Sites 438 and 439 . The fluctuation of $\delta^{18} \mathrm{O}$ of the interstitial water commonly tends to correlate with the lithology of sediments (Lawrence et al., 1975). As mentioned in the previous sections, geologic ages, sediment lithology, sediment accumulation rate, and depositional environments at Sites 438 and 439 are similar to those of Site 584 sediments; therefore, the pattern of $\delta^{18} \mathrm{O}$ of the interstitial water at Sites 438 and 439 is expected to be similar to the pattern at Site 584 .

\section{GEOTHERMAL GRADIENTS IN THE JAPAN TRENCH REGION}

During Leg 57, numerous temperature measurements were made in Holes 438A, 439, and 440A. In most cases, boreholes are cooled because of the circulation of the surface seawater or drilling mud; the measured temperatures, therefore, are usually somewhat lower than the equilibrium temperatures. Burch and Langseth (1981) estimated the effect of cooling caused by circulating water and calculated equilibrium temperatures in these holes. According to these researchers, geothermal gradients in Holes 438A and 439, about $110 \mathrm{~km}$ west of the trench axis, are $3.2^{\circ} \mathrm{C} / 100 \mathrm{~m}$ and $3.6^{\circ} \mathrm{C} / 100 \mathrm{~m}$ respectively, and in Hole $440 \mathrm{~B}$, about $40 \mathrm{~km}$ west of the trench axis, the equilibrium temperature is only $2.4^{\circ} \mathrm{C} / 100 \mathrm{~m}$. 


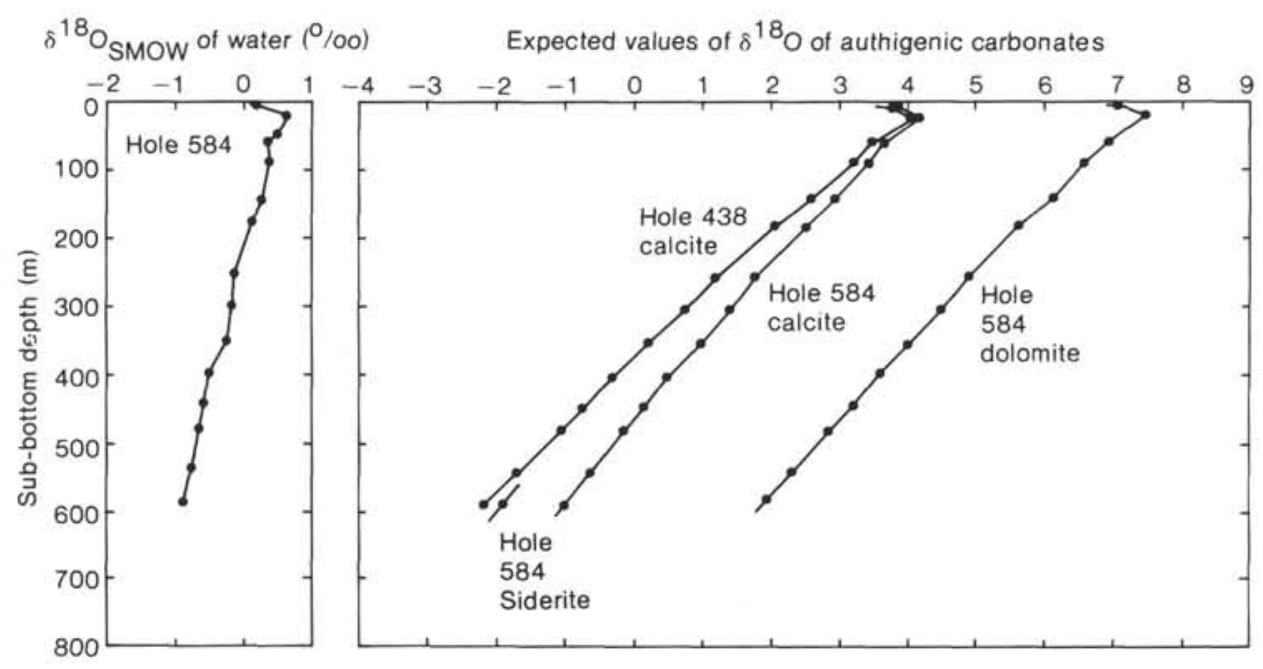

Figure 7. Oxygen isotope ratio of the interstitial water plotted against sub-bottom depth (after Matsuhisa and Matsumoto, this volume) and expected value of $\delta^{18} \mathrm{O}$ (in \%o versus PDB standard) of authigenic carbonates which are in equilibrium with the adjacent interstitial water. Geothermal gradients are $3.2^{\circ} \mathrm{C} / 100 \mathrm{~m}$ at Site 438 and $2.4^{\circ} \mathrm{C}$ at Site 584 (after Burch and Langseth, 1981). SMOW = standard mean ocean water.

Temperature measurements were not obtained at Site 584. Site 584 is located about $90 \mathrm{~km}$ north of Site 440 and $40 \mathrm{~km}$ west of the trench axis (Fig. 1). The heat flow contour pattern around the northeastern Japan arc nearly parallels the trench and reaches the minimum near the trench axis (Burch and Langseth, 1981). These facts suggest that the geothermal gradient at Site 584 is similar to that at Site 440. At Sites 438 and 439, opal-CT appears at around $700 \mathrm{~m}$ sub-bottom, where the temperature is $25-27^{\circ} \mathrm{C}$; clinoptilolite occurs below $950 \mathrm{~m}$ sub-bottom, where the temperature is $33-36^{\circ} \mathrm{C}$ (Iijima et al., 1980). Transformation of biogenic opal to opal-CT and of fresh volcanic glass to clinoptilolite are strongly temperature dependent, therefore these minerals are useful indicators of the burial temperature. Neither opal-CT nor clinoptilolite occur at Site 584 (total depth $=954 \mathrm{~m}$ ) in spite of the common occurrence of siliceous organisms and volcanic glass, suggesting that the geothermal gradient at Site 584 does not exceed $2.4-2.6^{\circ} \mathrm{C} / 100 \mathrm{~m}(25-$ $27^{\circ} \mathrm{C} / 954 \mathrm{~m}$ ). Hence, we assume that the geothermal gradient at Site 584 is $2.4^{\circ} \mathrm{C} / 100 \mathrm{~m}$ in the calculations that follow.

\section{EXPECTED VALUE OF $\delta^{18}$ O OF AUTHIGENIC CARBONATES}

The oxygen isotope ratio of carbonate minerals is determined principally by (1) $\delta^{18} \mathrm{O}$ of the water from which the carbonate precipitated, (2) temperature of precipitation, and (3) chemical composition of the carbonate. For calcite, the relation among $\delta^{18} \mathrm{O}$ of calcite $(\delta \mathrm{c}), \delta^{18} \mathrm{O}$ of water $(\delta \mathrm{w})$, and the formation temperature $(t)$ is

$$
t=16.5-4.3(\delta c-\delta \mathrm{w})+0.14(\delta \mathrm{c}-\delta \mathrm{w})^{2}
$$

(Epstein et al., 1953). Solving equation (1) for $\delta c$, we get

$$
\delta \mathrm{c}=15.4+\delta \mathrm{w}-\sqrt{7.18 t+118},
$$

so that given $t^{\circ} \mathrm{C}$ and $\delta^{18} \mathrm{O}$ of water, we can calculate the expected $\delta^{18} \mathrm{O}$ value of calcite precipitated in equilibrium with the water.

Reliable data on the isotopic fractionation between dolomite and water and between siderite and water at the low temperature range $\left(2-20^{\circ} \mathrm{C}\right)$ are not available. According to Fritz and Smith (1970), the fractionation constant $(\ln \alpha)$ between calcite and protodolomite is calculated to be $+2.3 \%$ in the temperature range $25-75^{\circ} \mathrm{C}$, using the acid fractionation factor of 1.01109 for dolomite and 1.01025 for calcite. We estimated the fractionation constant between calcite and dolomite, $\ln \alpha$ (dolomite - calcite), at $2-20^{\circ} \mathrm{C}$, extrapolating that value to the lower temperature range on a diagram prepared by Friedman and O'Neil (1977). The fractionation constant at $2^{\circ} \mathrm{C}$ thus estimated is

$$
1000 \ln \alpha(\text { dolomite }- \text { calcite })=3.2 \text {, }
$$

and at $20^{\circ} \mathrm{C}$ is

$$
1000 \ln \alpha(\text { dolomite }- \text { calcite })=2.7 .
$$

The fractionation constant commonly decreases with increasing temperature. Also, we can roughly estimate the fractionation between siderite and water, $\ln \alpha$ (siderite water), by use of the relation between the atomic weight of divalent cations and the fractionation constants of divalent metal carbonates. Based on the values of $\ln \alpha$ $\left(\mathrm{M} \cdot \mathrm{CO}_{2}-\mathrm{H}_{2} \mathrm{O}\right.$ ), where $\mathrm{M}$ is $\mathrm{Ca}, \mathrm{Mg}, \mathrm{Mn}, \mathrm{Sr}, \mathrm{Pb}$, and $\mathrm{Ba}$ (O'Neil, 1977), we estimated the fractionation between siderite and calcite at about $20^{\circ} \mathrm{C}$ to be

$$
1000 \ln \alpha(\text { siderite }- \text { calcite })=0.9
$$

Using the available data for both geothermal gradients and $\delta^{18} \mathrm{O}$ values of the interstitial water at Sites 438 , 
439, and 584 for any sub-bottom depth, we can estimate the values of $\delta^{18} \mathrm{O}$ of calcite, dolomite, and siderite precipitating in equilibrium with the interstitial water. The calculated $\delta^{18} \mathrm{O}$ values of carbonates are plotted against the depth of precipitation in Figure 7. Four solid lines connecting small solid circles show the variation of the expected $\delta^{18} \mathrm{O}$ values of calcite in Holes 438 and 584, of dolomite in Hole 584, and of siderite in Hole 584, respectively.

\section{ESTIMATION OF THE DEPTH OF FORMATION OF AUTHIGENIC CARBONATES}

Authigenic carbonates in isotopic equilibrium with adjacent interstitial water are expected to have the $\delta^{18} \mathrm{O}$ values represented by diagonal lines in Figure 8. However, as can be seen from Figure 8 , the actual $\delta^{18} \mathrm{O}$ values of carbonates are somewhat higher than the predicted values. For example, although calcite at $594 \mathrm{~m}$ sub-bottom at Site 584 is expected to have $-1 \% 0 \delta^{18} \mathrm{O}$, it actually has $+4.43 \% 0 \delta^{18} \mathrm{O}$; siderite at $720 \mathrm{~m}$ is expected to contain $-3.0 \% 0 \delta^{18} \mathrm{O}$, but it contains $-1.9 \% 0 \delta^{18} \mathrm{O}$. This disparity suggests that these authigenic carbonates are not in equilibrium with the coexisting interstitial water and probably did not and are not now precipitating at the present depths of occurrences, but probably were formed in the past at shallower depths of burial.

When we use the curves of the expected values of $\delta^{18} \mathrm{O}$ (Fig. 8) to estimate the depth at which carbonates precipitated, we make the two assumptions that the paleotemperature and the paleo- $\delta^{18} \mathrm{O}$ of the interstitial water were nearly the same as those observed today. Al- though it is difficult to estimate the paleotemperature and paleo- $\delta^{18} \mathrm{O}$ of the interstitial water, considering the geologic history and evolution of the northeastern Honshu arc, we can assume that the geothermal gradient has probably changed little since the middle Miocene (about $13 \mathrm{Ma}$ ). As stated above, Miocene to Pliocene sediments from Sites 438,439 , and 584 are mostly made up of the homogeneous diatomaceous mud and mudstone (Fig. 2), and the fluctuation of $\delta^{18} \mathrm{O}$ value of the interstitial water is controlled by the sediment lithology. Therefore, it is unlikely that the $\delta^{18} \mathrm{O}$ values of the interstitial water of Pliocene to Miocene time were significantly different from those observed now. If we accept these assumptions, the curves of the expected $\delta^{18} \mathrm{O}$ values (Fig. 8) are applicable to all the carbonate minerals in these sediments, regardless of the geologic age of their formation.

The substitution of magnesium influences the oxygen isotopic ratio of calcite. According to Tarutani and others (1969), ${ }^{18} \mathrm{O}$ fractionation in magnesian calcite relative to pure calcite precipitated under the same conditions changes by $0.06 \%$ for each mole-percent $\mathrm{MgCO}_{3}$ in calcite. When we project the measured $\delta^{18} \mathrm{O}$ of magnesian calcite to the respective curve of Figure 8, we have to correct the actual $\delta^{18} \mathrm{O}$ value by $0.06(\%) \times$ $\mathrm{MgCO}_{3}(\mathrm{~mol} . \%)$, in calcite. Corrected $\delta^{18} \mathrm{O}$ values are given in the sixth column of Table 1 . The L-shaped solid lines in Figure 8 demonstrate how to estimate the depth of precipitation of calcite. The horizontal part of the Lshaped line with small symbols at the bottom indicates the degree of shift of $\delta^{18} \mathrm{O}$ when corrected for $\mathrm{Mg}$ substitution; arrows and large symbols at the top of the verti-

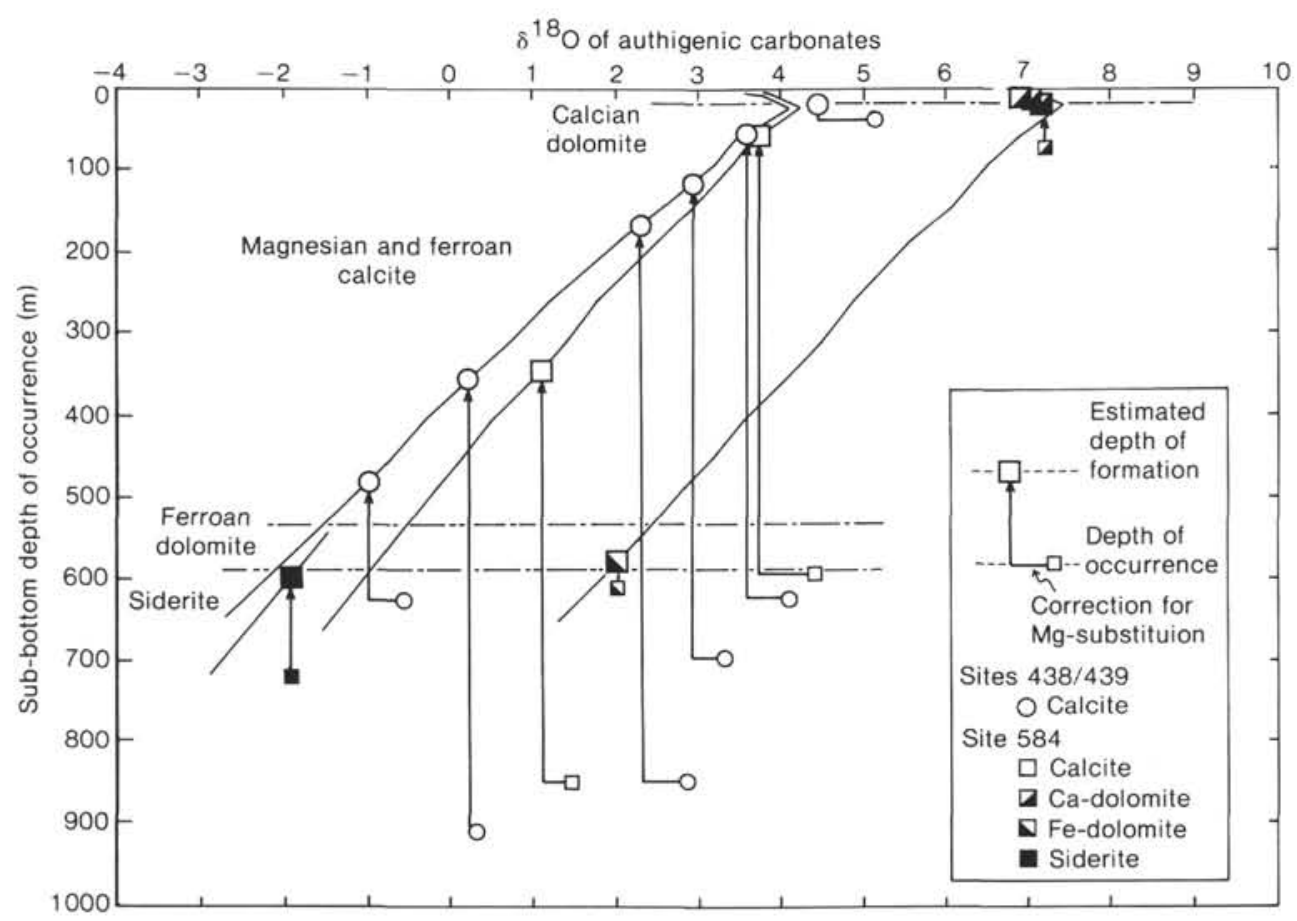

Figure 8. $\delta^{18} \mathrm{O}$ (in \%o versus PDB standard) of authigenic carbonates plotted against the sub-bottom depth of occurrence (small symbols) and estimated depth of formation (large symbols). Diagonal lines show the expected values of $\delta^{18} \mathrm{O}$ of carbonates (Fig. 7). Four carbonate mineral zones are distinguished in these sediments, as shown by broken lines. 


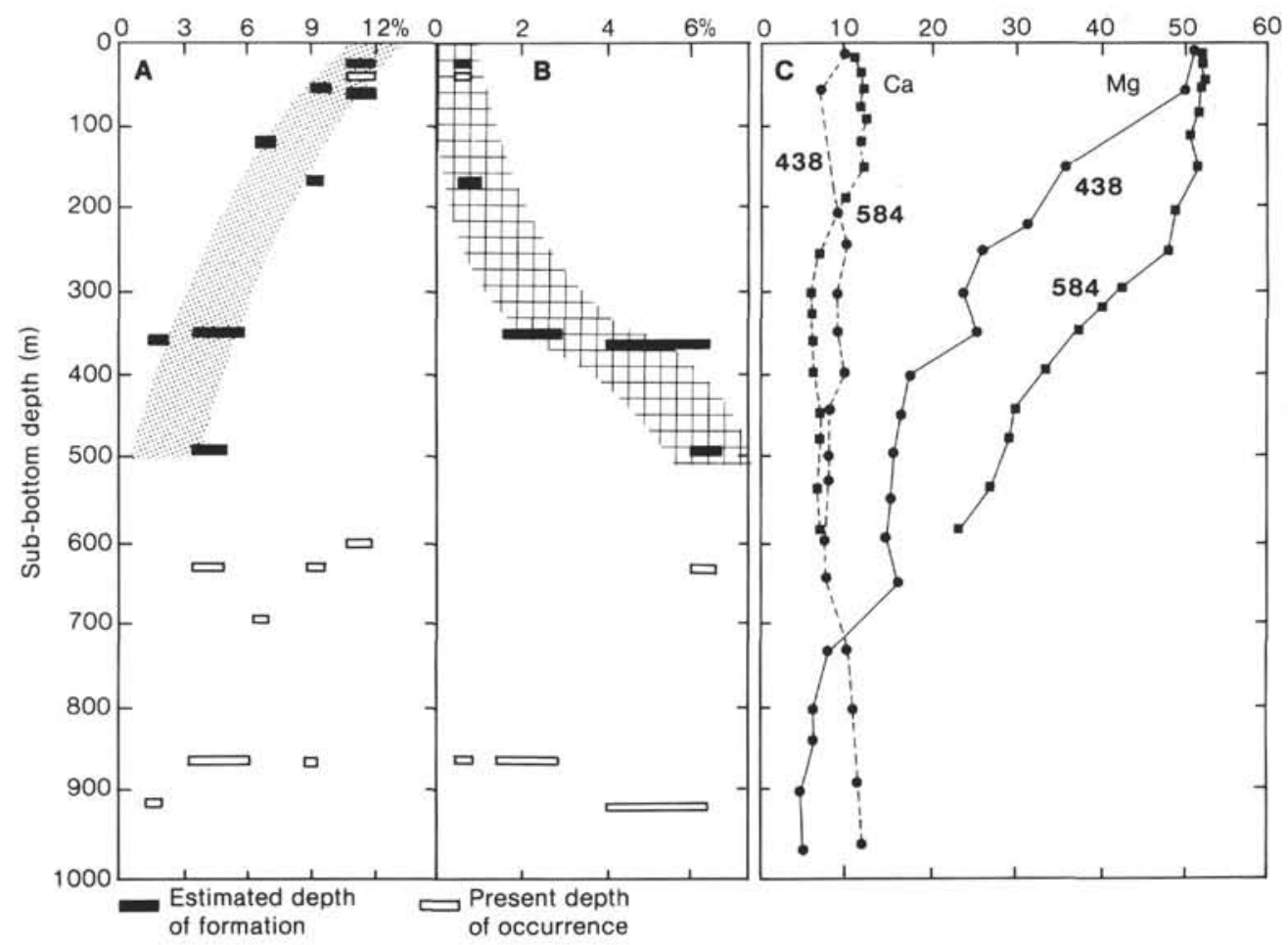

Figure 9. Variation diagrams showing the relation between the chemical composition of carbonate and the interstitial water chemistry. The solid rectangles in Parts A and B show the variation of $\mathrm{Mg}$ and $\mathrm{Fe}$ contents of calcite (in \%) with increasing depth of formation; open rectangles in these columns represent $\mathrm{Mg}$ and $\mathrm{Fe}$ contents of calcite plotted against the present depth of occurrence. Part $\mathrm{C}$ shows $\mathrm{Ca}^{++}$and $\mathrm{Mg}^{++}$concentrations of the interstitial water (in $\mathrm{mM} / \mathrm{kg}$ ). Interstitial water chemistry was taken from Scientific Party (1980, Leg 57) and site chapter, Site 584 (this volume).

cal line indicate the estimated depth of formation. Substitution effects were not considered for dolomite and siderite because these data are not available for these carbonates. So the depth of formation of dolomite and siderite is indicated only by the vertical line. The effect of substitution on the oxygen isotope ratio in dolomite and siderite is inferred to be less than $0.5 \%$ from the amount of shift measured from Mg-calcite. So the "true" depths of formation of dolomite and siderite are not likely to differ significantly from those estimated in Figure 8 .

Both calcian and ferroan dolomite plot near the dolomite curve, so the difference between the actual subbottom depth and the estimated depth of formation $(\Delta \mathrm{d})$ is small, 1 to $62 \mathrm{~m}$ for these phases (Fig. 8); however, $\Delta \mathrm{d}$ can exceed $500 \mathrm{~m}$ for some calcites. For example, calcite at $841 \mathrm{~m}$ sub-bottom $\left(439-5-2 ;+2.88 \% 0 \delta^{18} \mathrm{O}\right)$ is estimated to have been formed under only $165 \mathrm{~m}$ of overburden, $686 \mathrm{~m}$ shallower than the present sub-bottom depth.

The most important finding shown in Figure 8 and Table 1 is that different carbonate minerals were formed successively in the sediments with increasing depth. From shallow to deep, they are calcian dolomite, calcite, ferroan dolomite, and siderite.

\section{STAGES OF CARBONATE AUTHIGENESIS}

Calcian dolomite is formed at depths shallower than $15 \mathrm{~m}$; calcite, between 25 and $480 \mathrm{~m}$; ferroan dolomite, approximately $580 \mathrm{~m}$; and siderite, near or deeper than $600 \mathrm{~m}$ (Fig. 8). Based on the regular distribution of the depth of formation of authigenic carbonates, four stages of carbonate authigenesis are defined: Stage I, calcian dolomite; Stage II, calcite; Stage III, ferroan dolomite; and Stage IV, siderite. The boundaries between these stages are approximately $20 \mathrm{~m}$ (I/II), $530 \mathrm{~m}$ (II/ III), and $590 \mathrm{~m}$ (III/IV). The sequence of formation of deep-sea carbonates is consistent with the sequence of formation of $\mathrm{Ca}-\mathrm{Mg}$-Fe carbonates in the shallow marine sediments exposed on land (Matsumoto, 1978; Matsumoto and Iijima, 1981).

Covariation diagrams of the chemical composition and the estimated depth of formation of calcite in Stage II are shown in Figure 9, which also illustrates the concentration of $\mathrm{Ca}^{++}$and $\mathrm{Mg}^{++}$of the interstitial water. The Mg-content of calcites decreases with increasing depth of formation. This pattern is consistent with the $\mathrm{Mg}^{++}$ variation of the interstitial water; $\mathrm{Mg}^{++}$is about 50 $\mathrm{mM} / \mathrm{kg}$ above $100 \mathrm{~m}$ sub-bottom but it is only $10-20$ $\mathrm{mM} / \mathrm{kg}$ at $\sim 500 \mathrm{~m}$. The successive precipitation of dolomite, high-magnesian calcite, and then low-magnesian calcite is also reasonable and consistent with the decrease in $\mathrm{Mg}^{++}$of the interstitial water. The above lines of evidence confirm our former assumptions that the paleotemperature and paleo- $\delta^{18} \mathrm{O}$ value of the interstitial water were not greatly different from those measured at present. The chemical composition of calcite versus present-day sub-bottom depths (open rectangle) do not 
show a regular pattern of variation (Fig. 9). Based on the $\mathrm{Mg}$ content, Stage II is divided into two substages; IIa (magnesian calcite) and IIb (ferroan calcite). The boundary between IIa and $\mathrm{IIb}$ is $\sim 250 \mathrm{~m}$. Comparing the $\mathrm{Mg}$ content in calcite and the $\mathrm{Mg}^{++} / \mathrm{Ca}^{++}$ratio of the interstitial water, we calculate the partition coefficient of magnesium between calcite and water to be $0.01-0.02$. This range includes the experimental value, 0.02 , given by Glover and Sippel (1967).

The $\mathrm{Fe}$ content of calcite also varies regularly with estimated depth of formation (Fig. 9); the content increases from less than $1 \mathrm{~mol} . \%$ at $25 \mathrm{~m}$ to about $7 \mathrm{~mol} . \%$ at $480 \mathrm{~m}$. Similar to $\mathrm{Mg}^{++}$, this pattern probably reflects the variation of the chemistry of the interstitial water. Ferric oxide and hydroxide are reduced to ferrous iron in deep anaerobic sediments and $\mathrm{Fe}^{++}$concentration gradually increases downward. $\mathrm{S}^{--}$concentration decreases drastically because of the rapid consumption of sulfate at shallow levels and the precipitation of pyrite. Consequently, ferrous iron does not precipitate as pyrite in deeper levels but as ferrous carbonates, such as ferroan calcite, followed by ferroan dolomite and finally by siderite. An increase of $\mathrm{Fe}$ content in authigenic carbonates with depth is thoroughly discussed by Curtis (1977). The formation of ferroan dolomite after ferroan calcite seems to oppose the general trend of formation, because the $\mathrm{Fe}$ content decreases from $7 \mathrm{~mol} . \%$ in ferroan calcite to $4 \mathrm{~mol} . \%$ in ferroan dolomite and the $\mathrm{Mg}$ content increases from 5 to $45 \mathrm{~mol} . \%$. This apparent reverse trend may indicate a change in evolution of the interstitial water chemistry at $\sim 500 \mathrm{~m}$ or, alternatively, it may be due to the difference in the activity coefficients of $\mathrm{Mg}$ and $\mathrm{Fe}$ in different carbonate phases.

The arrows in Figures 4 and 5 show the sequence of formation of authigenic carbonates and the compositional relations between calcite, dolomite, and siderite formed in succession. At the beginning of carbonate authigenesis, nearly pure dolomite with about $1 \mathrm{~mol} . \%$ excess $\mathrm{Ca}$ precipitates, which is followed by more calcium-rich dolomite (Stage I). When the $\mathrm{Ca}$ content in dolomite reaches $6 \mathrm{~mol} . \%$, dolomite ceases to precipitate and high-magnesian calcite with up to $12 \mathrm{~mol} . \%$ $\mathrm{Mg}$ starts to precipitate (Stage II). Calcite composition changes successively from high magnesian (Stage IIa) to feroan (Stage IIb). When the Fe content in calcite reaches $7 \mathrm{~mol} . \%$, calcite ceases to precipitate and ferroan dolomite with up to $4.5 \mathrm{~mol} . \% \mathrm{Fe}$ and $58 \mathrm{~mol} . \% \mathrm{Ca}$ precipitates (Stage III). In ferroan dolomite the Ca content gradually decreases, and when it reaches $52 \mathrm{~mol} . \%$, magnesian siderite is formed (Stage IV).

\section{$\delta^{13} \mathrm{C}$ AND THE ORIGIN OF $\mathrm{CO}_{2}$}

$\delta^{13} \mathrm{C}$ of authigenic carbonates decreases suddenly from $-13 \%$ at $1 \mathrm{~m}$ to $-37 \%$ at $55 \mathrm{~m}$, and then it reverses to $-27 \% 0$ at $120 \mathrm{~m}$ and $-4.3 \% 0$ at $165 \mathrm{~m}$ sub-bottom (Fig. 10). $\delta^{13} \mathrm{C}$ of carbonates formed in the deeper levels lies between -4 and $+11 \%$ regardless of the various mineralogy and chemistry of carbonates.

Organic materials in marine sediments are decomposed through three main processes: (1) oxidation; (2) sulfate reduction; and (3) methane fermentation (Irwin et al., 1977). Of these processes, oxidation and sulfate reduction generally dominate at relatively shallow depths (where free oxygen and sulfate are abundant) and generate light carbon $\mathrm{CO}_{2}$, whereas methane fermentation predominates at the deeper levels and commonly produces heavy carbon $\mathrm{CO}_{2}$, because ${ }^{13} \mathrm{C}$ is enriched in $\mathrm{CH}_{4}$ relative to coexisting $\mathrm{CO}_{2}$.

Considering these three processes that generate $\mathrm{CO}_{2}$, the fluctuating pattern of $\delta^{13} \mathrm{C}$ of carbonates can be explained as the result of the changing origin of the $\mathrm{CO}_{2}$ with increasing depth. The stages of calcian dolomite and magnesian calcite are characterized by oxidation and/or sulfate reduction. Methane oxidation at shallow levels after upward diffusion/migration can produce extremely light carbon; this process could form these very light carbon carbonates. The increase in $\delta^{13} \mathrm{C}$ from -37 to $-4.3 \%$ at $\sim 100 \mathrm{~m}$ probably means that the fermentation-derived $\mathrm{CO}_{2}$ dominates over the $\mathrm{CO}_{2}$ generated through oxidation and/or sulfate reduction. Stages IIb, III, and IV are all characterized by fermentation-derived $\mathrm{CO}_{2}$. These interpretations are supported by the interstitial water chemistry and gas analyses (Fig. 10). Sulfate concentration is about one-tenth that of seawater in shallow depths, then drastically decreases from about 7 to 2 $\mathrm{mM} / \mathrm{kg}$ at $\sim 200 \mathrm{~m}$ sub-bottom, whereas $\mathrm{CH}_{4}$ increase markedly at $\sim 150 \mathrm{~m}$. The decrease of $\mathrm{SO}_{4}$ concentration is consistent with decreasing light carbon $\mathrm{CO}_{2}$ derived from sulfate reduction. The increase of $\mathrm{CH}_{4}$ reflects dominant methane fermentation, suggesting an increase of heavy carbon $\mathrm{CO}_{2}$.

\section{SUMMARY AND CONCLUSION}

1. Carbonate concretions are found in Pliocene to Miocene diatomaceous mud and mudstone at Sites 438, 439 , and 584 on the deep-sea terrace near the Japan Trench. Concretions are composed of magnesian to ferroan calcite (5-12 mol.\% $\mathrm{Mg}, 0-7 \mathrm{~mol} \% \mathrm{Fe}$ ), calcian dolomite (51-56 mol. \% Ca, $0 \mathrm{~mol} . \% \mathrm{Fe})$, ferroan dolomite (52-58 mol.\% Ca, 2.5-4 mol.\% Fe), and magnesian siderite $(30-34 \mathrm{~mol} . \% \mathrm{Mg}, 10-13 \mathrm{~mol} . \% \mathrm{Ca})$. Chemical composition of constituent carbonates is unlikely to be correlated to the present sub-bottom depth of occurrence of the concretions.

2. $\delta^{18} \mathrm{O}$ tends to be concentrated in calcian dolomite $(+7.77$ to $+8.09 \%)$ rather than calcite $(-0.81$ to $+5.15 \% 0)$, ferroan dolomite $(+2.00 \%)$, and siderite $(-1.90 \%)$. $\delta^{13} \mathrm{C}$ ranges widely between -36.96 and $+11.45 \%$.

3. Given that the paleotemperature and paleo- $\delta^{18} \mathrm{O}$ values of the interstitial water were similar to those observed at present, we can estimate the burial depth at which authigenic carbonates formed, using the "oxygen isotope thermometer" of authigenic carbonates.

4. Based on the estimated depth of formation, four stages of carbonate authigenesis are defined at Stage I, calcian dolomite; Stage IIa, magnesian calcite; Stage IIb, ferroan calcite; Stage III, ferroan dolomite; and Stage IV, siderite. The boundaries between Stages I/II, II/ III, and III/IV are placed at approximately 20,530, and $590 \mathrm{~m}$, respectively. The sequence of formation of these four carbonate phases is consistent with the sequence of formation of authigenic carbonates in the Paleogene coal measures exposed on land. 


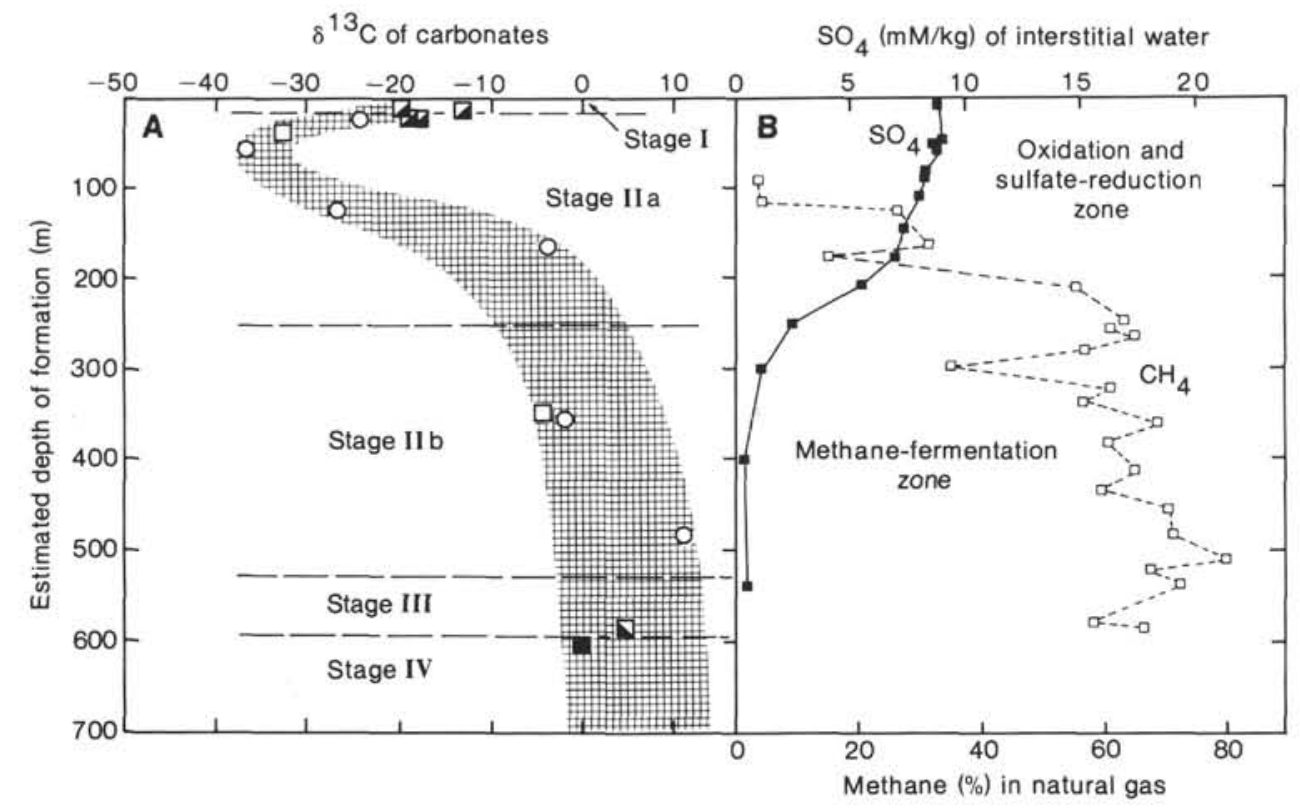

Figure 10. A. Variation of $\delta^{13} \mathrm{C}$ (in $\%$ versus PDB standard) of authigenic carbonates against the estimated depth of formation. (For explanation of stages, see text.) Symbols are the same as in Fig. 8 . Hatched area shows general trend of the fluctuation of $\delta^{13} \mathrm{C}$ of carbonates. $\mathrm{B} . \mathrm{SO}_{4}$ concentration in the interstitial water (B. Takano, personal communication, 1985) and $\mathrm{CH}_{4}$ (methane) in the dissolved natural gas (Scientific Party, 1980).

5. Progressive changes in mineralogy and chemistry of these marine authigenic carbonates with estimated depths of formation are quite consistent with the interstitial water chemistry observed at present. This agreement suggests that changes in mineral phase are not a "steady state process" (Berner, 1980), whereas the interstitial water chemistry changes with depth, independent of time.

6. The fluctuation of $\delta^{13} \mathrm{C}$ of carbonates clearly indicates the origin of $\mathrm{CO}_{2}$ (oxidation and sulfate reduction during Stages I and IIa and methane fermentation during Stages IIb, III, and IV).

\section{ACKNOWLEDGMENTS}

We are grateful to Professors C. D. Curtis of the University of Sheffield, A. J. Smith of the University of London, A. Iijima of the University of Tokyo, and Drs. J. R. Hein of the U.S. Geological Survey and C. L. Stein of the Sandia Laboratories for reading the manuscript. Mr. Y. Morishita kindly assisted us in preparing the gas sample for isotopic analysis. This research was supported by a grand-in-aid from the Ministry of Education and Culture and the Ito Science Foundation.

\section{REFERENCES}

Berner, R. A., 1980. Early Diagenesis, A Theoretical Approach. Princeton (Princeton University Press).

Burch, T. K., and Langseth, M. G., 1981. Heat flow determination in the DSDP Holes near Japan Trench. J. Geophys. Res., 80:94119419.

Curtis, C. D., 1977. Sedimentary geochemistry: environments and processes dominated by involvement of aqueous phases. Phils. Trans, $R$. Soc. London, Ser. A, 286:353-372.

Epstein, S., Buchsbaum, R., Lowenstram, H. A., and Urey, H. C., 1953. Revised carbonate-water temperature scale. Geol. Soc. Am. Bull., 62:417-426.

Friedman, I., and O'Neil, J. R., 1977. Compilation of Stable Isotope Fractionation Factors of Geochemical Interest. U.S. Geol. Surv., Prof. Paper, 440-KK.

Fritz, P., and Smith, D. C. W., 1970. The isotopic composition of secondary dolomite. Geochim. Cosmochim. Acta, 34:1161-1173.
Glover, E. D., and Sippel, R. F., 1967. Synthesis of magnesian calcites. Geochim. Cosmochim. Acta, 31:603-613.

Hein, J. R., O'Neil, J. R., and Jones, M. G., 1979. Origin of authigenic carbonates in sediments from the deep Bering Sea. Sedimentology, 26:681-705.

Iijima, A., Matsumoto, R., and Tada, R., 1980. Zeolite and silica diagenesis and sandstone petrography at Sites 438 and 439 off Sanriku, Northwest Pacific, Leg 57, Deep Sea Drilling Project. In Scientific Party, Init. Repts. DSDP, 56, 57 Pt. 2: Washington (U.S. Govt. Printing Office), 1143-1158.

Irwin, H., Curtis, C. D., and Coleman, M., 1977. Isotopic evidence for source of diagenetic carbonates formed during burial of organic-rich sediments. Nature, 269:209-213.

Lawrence, J. R., Gieskes, J. M., and Broecker, W. S., 1975. Oxygen isotope and cation composition of DSDP pore water and the alteration of layer II basalt. Earth Planet. Sci. Lett., 27:1-10.

Matsumoto, R., 1978. Occurrence and origin of authigenic Ca-Mg-Fe carbonates and carbonate rocks in the Paleogene coalfield regions in Japan. J. Fac. Sci. Univ. Tokyo, Sec. 2, 19:335-367.

Matsumoto, R., and Iijima, A., 1980. Carbonate diagenesis in cores from Sites 438 and 439 off northeast Honshu, northwest Pacific. Leg 57, Deep Sea Drilling Project. In Scientific Party, Init. Repts. DSDP, 56, 57, Pt. 2: Washington (U.S. Govt. Printing Office), $1117-1131$

, 1981. Origin and diagenetic evolution of $\mathrm{Ca}-\mathrm{Mg}-\mathrm{Fe}$ carbonates in some coalfields in Japan. Sedimentology, 28:239-259.

O'Neil, J. R., 1977. Stable isotopes in mineralogy. Phys. Chem. Mineral., 2:105-123.

Scientific Party, 1980. Sites 438 and 439: Japan deep sea terrace, Leg 57. In Scientific Party, Init. Repts. DSDP, 56, 57, Pt. 1: Washington (U.S. Govt. Printing Office), 23-191.

Sharma, T., and Clayton, R. N., 1965. Measurement of $\mathrm{O}^{18} / \mathrm{O}^{16} \mathrm{ra}-$ tios of total oxygen of carbonates. Geochim. Cosmochim. Acta, 29:1347-1353.

Tarutani, T., Clayton, R. N., and Mayeda, T. K., 1969. The effect of polymorphism and magnesium substitution of oxygen isotope fractionation between calcium carbonate and water. Geochim. Cosmochim. Acta, 33:987-996.

Date of Initial Receipt: 10 November 1983

Date of Acceptance: 25 May 1985 